\title{
PEMANFAATAN EKSTRAK UBI UNGU SEBAGAI INDIKATOR LABEL DALAM PEMANTAUAN KESEGARAN UDANG MENGUNAKAN NEURAL NETWORK
}

\author{
Siswoyo ${ }^{1}$, Anisah Mega Andini ${ }^{2}$, Dea Amelia ${ }^{1}$, Aisyah D. A. T. Safitri ${ }^{1}$ dan Yuant Tiandho ${ }^{1 *}$ \\ ${ }^{1}$ Jurusan Fisika, Teknik, Universitas Bangka Belitung, Kampus Terpadu UBB, Balunijuk, Kabupaten Bangka, 33172, Indonesia \\ ${ }^{2}$ Jurusan Akuakultur, FPPB, Universitas Bangka Belitung, Balunijuk, Kabupaten Bangka, 33172, Indonesia \\ *e-mail: yuant@ubb.ac.id
}

\begin{abstract}
ABSTRAK
Salah satu permasalahan utama dalam pemasaran udang adalah udang mudah mengalami pembusukan. Umumnya, masyarakat mengidentifikasi kesegaran udang dengan pengamatan langsung. Namun, sulit mendeteksi kesegaran udang jika pemasarannya dalam wadah tertutup. Pada penelitian ini telah dibuat indikator label dari ubi jalar ungu untuk mendeteksi kesegaran udang. Selain itu, kami juga menggunakan neural network untuk klasifikasi warna indikator label. Hasil pengujian sensitivitas menunjukan indikator label dari ekstrak ubi ungu sensitif terhadap keberadaan amoniak. Melalui perbandingan antara lama penyimpanan udang dengan kualitas organoleptik udang diketahui bahwa kualitas udang dibedakan menjadi empat kelas, yaitu: yaitu (i) "Sangat Segar (SS)" ditandai warna merah pekat (ii) "Segar (S)" ditandai warna biru pekat (iii) "Tidak Segar (TS)" ditandai warna abu-abu dan (iv) "Sangat Tidak Segar (STS)" ditandai warna coklat pudar. Melalui klasifikasi citra indikator label menggunakan algoritma neural network dari 73 data training diperoleh tingkat akurasi sebesar 95,89\% dan presisi sebesar $92 \%$.
\end{abstract}

Kata Kunci: Indikator; Ubi jalar ungu; Udang; Neural network

\section{ABSTRACT}

[Title: Utilization Of Purple Sweet Potato Extract As A Label Indicator In Monitoring The Freshness Of Shrimp Using A Neural Network] One of the main problems in shrimp marketing is that shrimp are prone to spoilage. Generally, people identify the freshness of shrimp by direct observation. However, it is not easy to detect the freshness of shrimp if it is marketed in a closed container. In this study, a label indicator of purple sweet potato was made to detect the freshness of shrimp. In addition, we also use a neural network for the color classification of label indicators. The sensitivity test results showed that the label indicator of purple sweet potato extract was sensitive to the presence of ammonia. Through a comparison between the length of storage of shrimp and the organoleptic quality of shrimp, it is known that the quality of shrimp is divided into four classes, namely: (i) "Very Fresh (SS)" marked in dark red (ii) "Fresh (S)" marked in dark blue (iii) "Not Fresh (TS)" is marked in gray color and (iv) "Very Not Fresh (STS)" is marked in faded brown. Through label indicator image classification using a neural network algorithm from 73 training data obtained an accuracy rate of $95.89 \%$ and a precision of $92 \%$.

Keywords: Indicator; Purple sweet potato; Shrimp; Neural network

\section{PEDAHULUAN}

Produksi udang di Indonesia terus mengalami peningkatan sekitar sekitar 7,4\% per tahun. Hal ini menjadikan udang sebagai salah satu sektor perikanan indonesia dengan tingkat pemesanan dan pemasaran terbanyak baik dalam negeri maupun luar negeri (Fatimah, et al., 2020).

Udang merupakan bahan makanan yang sangat diminati karena mengandungkadar air dan gizi tinggi seperti protein, vitamin, mineral dan asam lemak yang baik untuk kesehatan, pertumbuhan dan perkembangan tubuh manusia (Ngginak,et al., 2013). Namun, tingginya kandungan gizi dan kadar air (80\%) serta $\mathrm{pH}$ yang netral dalam udang mendukung pertumbuhan dan pekembangan bakteri pembusuk maupun mikroorganisme lainnya, sehingga udang mudah mengalami pembusukan (perishable food) dan penurunan kualitas (Puspitasari, 2020). Oleh karena itu, pentingnya untuk memantau kualitas kesegaran udang, karena mengonsumsi udang yang telah busuk berbahaya bagi kesehatan (Du, et al., 2015). 
Penurunan kualitas udang dapat ditunjukkan oleh perubahan warna, aroma, dan rasa (Gustina, et al., 2015; Rahmat, et al., 2019). Umumnya, masyarakat mengidentifikasi kesegaran udang dengan pengamatan langsung melalui indera penglihatan, penciuman ataupun perasa. Cara tersebut kurang efisien jika dilakukan pada udang yang sudah dikemas. Selain itu hasil pengamatan tersebut akan bervariasi tergantung pada persepsi tiap individu. Spektrofotometer, analisis citra dan sensor ultrasonic merupakan metode untuk menenukan kesegaran udang dalam kemasan tertutup, namun metode tersebut cenderung mahal sehingga sulit untuk diaplikasikan secara luas dimasyarakat (Alimelli, et al., 2007).

Salah satu metode alternatif yang dapat dikembangkan untuk mengatasi permasalahan penentuan kesegaran udang dalam kemasan adalah melalui pemanfaatan indikator kolorimetri. Indikator kolorimetri yang paling banyak dikembangkan untuk mendeteksi kebusukan udang salah satunya adalah indikator pH (Imawan, et al., 2018). Pada indikator $\mathrm{pH}$ warna indikator secara fundamental akan berubah karena terjadi perubahan $\mathrm{pH}$ lingkungan. Saat ini, pengembangan indikator pH dilakukan dengan memanfaatkan bahan pewarna alami yang ramah lingkungan dan aman untuk makanan.

Salah satu pewarna alami yang berpotensi digunakan untuk indikator label yang jumlahnya melimpah adalah ubi jalar ungu (Arifuddin, 2018). Ubi jalar ungu mengandung antosianin yang peka terhadap perubahan pH (Achmad \& Sugiarto, 2020). Ubi jalar ungu merupakan salah satu ubi jalar yang banyak dijumpai di Indonesia dan mengandung pigmen antosianin paling tinggi di banding ubi jalar jenis lainnya (Ananta, et al., 2017).

Peningkatkan efisiensi deteksi tingkat kesegaran udang dilakukan menggunakan citra pada perubahan warna label indikator melalui teknologi klasifikasi dengan neural network (Yanto, 2017). Adanya teknologi klasifikasi tersebut pada indikator label diharapkan dapat menarik perhatian untuk dilakukan pengembangan penelitian seperti, sistem monitoring kesegaran udang yang tidak hanya dapat menampilkan kualitas udang melainkan juga dapat menunjukan lama waktu penyimpanan udang sehingga, sistem tersebut dan dapat digunakan oleh semua kalangan bahkan para penyandang buta warna sekalipun.

\section{METODE}

Alat yang digunakan pada penelitian ini meliputi gelas beaker, gelas ukur, labu ukur, timbangan digital, corong gelas, batang pengaduk kaca, pipet tetes, botol kaca, pH meter, kamera smartphone 13 MP, blender, pinset, hotplate stirrer, dan kotak plastik dan seperngkatstudio foto mini yang dilengkapi dengan lampu LED. Bahan yang digunakan pada peneltian ini meliputi ubi ungu, udang, tissue, etanol 96\%, aquadest, $\mathrm{HCl} 1 \mathrm{M}$, $\mathrm{NaOH} 1 \mathrm{M}$, amonia $0,5 \%$, dan kertas saring whatman no 41 , dan plastk warp.

\section{Prosedur Penelitian}

Penelitian ini meliputi beberapa tahapan yaitu: (i) preparasi ubi ungu, (ii) pembuatan ekstrak ubi ungu, (iii) pembuatan indikator label, (iv) pengujian sensitivitas indikator label dan (v) pengolahan data dengan neural network.

\section{Preparasi Ubi Ungu}

Sebanyak $2 \mathrm{~kg}$ ubi ungu dicuci dan dikeringkan dengan tissue. Kemudian, ubi ungu dipotong tipis dan dikeringkan dibawah sinar matahari. Selanjutnya ubi ungu dihaluskan dengan blender sehingga, didapatkan serbuk ubi ungu.

\section{Pembuatan Ekstrak Ubi Ungu}

Sebanyak165 gramserbuk ubi ungu dicampurkan dengan pelarut etanol 96\% sebanyak $220 \mathrm{ml}$. Campuran tersebut didiamkan selama 24 jam pada suhu kamar $\left(30^{\circ} \mathrm{C}\right)$. Selanjutnya, campuran disaring sehingga diperoleh ekstrak dari ubi ungu. Ekstrak tersebut disimpan dalam lemari pendingin untuk proses selanjutnya.

\section{Pembuatan Indikator Label}

Ekstrak ubi ungu dimasukan kedalam gelas beaker lalu dipanaskan dengan menggunakan hotplate Stirrer selama 10 menit. $\mathrm{pH}$ ekstrak tersebut diatur menjadi pH 2 menggunakan $\mathrm{HCl} 1 \mathrm{M}$. Pembuatan kertas indikator label dilakukan dengan memotong kertas saring whatman no. 41 dengan ukuran 6x1 $\mathrm{cm}$. Selanjutnya, kertas indikator label direndam didalam ekstrak ubi ungu selama 60 detik, dikeringkan dan simpan diwadah tertutup pada suhu ruang.

\section{Pengujian Sensitivitas Indikator Label}

Pengujian sensitivitas indikator label terhadap kebusukan udang dilakukan dengan mengamati perubahan warna indikator label dalam wadah botol kaca tertutup yang terdapat udang didalamnya pada suhu ruang $\left(30{ }^{\circ} \mathrm{C}\right)$. Proses pengambilan data dilakukan dengan meletakan botol kaca berisi udang dan indikator label kedalam studo foto mini dengan pencahayaan yang berasal dari lampu LED setiap 20 menit sekali selama 24 jam. Penggunaan perangkat studio foto mini dimaksudkan agar pengambilan foto 
dilakukan pada pencahayaan yang konsisten. Pengambilan foto perubahan warna indikator label dilakukan menggunakan kamera smatrphone dengan jarak antara botol sampel dan kamera yaitu $6 \mathrm{~cm}$.

\section{Pengolahan Data Dengan Neural Network.}

Pengolahan data berupa foto perubahan warna indikator label dilakukan menggunakan algoritma Neural Network pada software Wolfram Mathematica 11.3 dengan perangkat berspesifikasi prosesor Intel(R) Celeron(R) CPU N3350 @ $1.10 \mathrm{GHz} 1.10 \mathrm{GHz}$ (RAM 2GB). Foto perubahan warna indikator label dikuantisasi untuk mengurangi jumlah ketidakhomogenan warna pada foto, sehingga menghasilkan satu jenis warna tetapi tetap mempresentasikan citra atau foto tersebut.

Perhitungan akurasi dan presisi hasil pengujian sistem algoritma neural network mengguakan metode Confusion Matrix Multi-Class Classification $4 \times 4$ yaitu

Akurasi $=\frac{\mathrm{Tp}}{\text { Jumlah Data }} \times 100 \%$

Presisi Tp Kelas $\mathrm{i}=\frac{\mathrm{Tp} i}{\mathrm{Tp} i+\mathrm{Fp}}$

Presisi semua kelas $=\frac{\text { Presisi Tp Kelas }}{\text { Jumlah Kelas }} \times 10$

Keterangan : Tp (True positive); Tpi(True positive kelas i); Fp (False positive).

\section{HASIL DAN PEMBAHASAN}

Setelah dilakukan proses ekstraksi serbuk ubi ungu dengan menggunakan pelarut etanol 96\%, didapatkan ekstrak ubi ungu berwarna merah. Selanjutnya, ekstrak tersebut di dipanaskan dengan hotplate stirrer selama 10 menit untuk menghasilkan ekstrak kental. Selanjutnya, ekstrak kental di atur pH-nya menjadi pH 2 menggunakan $\mathrm{HCl} 1 \mathrm{M}$ sehingga didaptkan ekstrak berwarna merah pelat seperti pada Gambar 1.

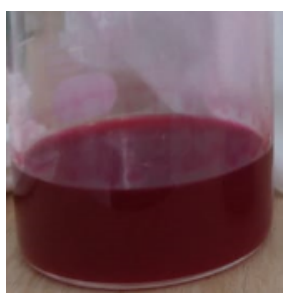

Gambar 1. Ekstrak ubi ungu

Pembuatan indikator label dilakukan dengan mencelupkan kertas indikator label kedalam ekstrak ubi ungu yang sudah diatur pH-Nya selama 60 detik, selanjutnya indikator tersebut di keringkan pada suhu ruang.

Setelah dilakukan pengujian sensitivitas indikator label terhadap kebusukan udang selama 24 jam, didapatkan 73 data berupa perubahan warna indikator label dari merah pekat menjad biru pekat, abu-abu, dan coklat pudar. Perubahan warna tersebut dipengaruhi oleh keberadaan jumlah amoniak yang diemisikan oleh udang selama proses pembusukan. Jumlah amoniak akan terus bertambah karena semakin lama udang simpan pada suhu ruang, maka jumlah kadar amoniak yang dilepas semakin banyak sehingga terjadi perbedaan perubahan warna indikator label dalam setiap jamnya (Noor, 2021; Watson,1939). Sehingga indikator label dari ekstrak ubi ungu sensitif terhadap keberadaan amoniak. Selanjutnya, data pengujian sensitivitas dikuantisasi warna agar menghasilkan satu jenis warna untuk mempermudah proses klasifikasi.

Klasifikasi dilakukan dengan mencocokan antaradatakualitas udang dengan waktu penyimpanan melalui uji organolepik yang dilakukan oleh Ali $\mathrm{dkk}$.Hasil penocokan tersebut diperoleh hubungan antara perubahan warna indikator label terhadap kualitas udang seperti pada Gambar 2. Sehingga didapatkan kategori klasifikasi kualitas udang pada indikator label yaitu: (i) "Sangat Segar (SS)" ditandai warna merah pekat (ii) "Segar (S)" ditandai warna biru pekat (iii) "Tidak Segar (TS)" ditandai warna abu-abu dan (iv) "Sangat Tidak Segar (TTS)" ditandai warna coklat pudar.

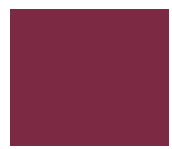

Sangat

Segar

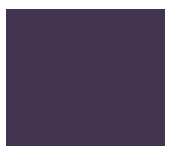

Segar

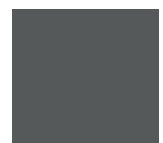

Tidak Segar

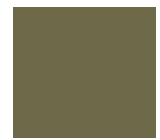

Sangat

Tidak
Gambar 2. Hubungan kualitas udang dengan indikator warna

Selanjutnya sebanyak 73 data kuantisasi warna indikator label agar menghasilkan satu jenis warna untuk mempermudah proses klasifikasi. Kemudian dilakukan pembagian data untuk keperluan pengujian dan training pada klasifikasi indikator label dengan sistem algoritma neural network. Hasil pengujian dan training disajikan pada Tabel 1. Dari 73 data terdapat 70 data yang sesuai dan 3 data yang tidak sesuai dengan data uji. 
Tabel 1. Perbandingan klasifikasi berdasarkan pengukuran organoleptik dan neural network

\begin{tabular}{|c|c|c|c|}
\hline No & $\begin{array}{c}\text { Citra indikator } \\
\text { label }\end{array}$ & $\begin{array}{c}\text { Klasifikasi } \\
\text { Organoleptik }\end{array}$ & $\begin{array}{c}\text { Prediksi } \\
\text { Neural } \\
\text { Network }\end{array}$ \\
\hline 1 & & Sangat Segar & $\begin{array}{l}\text { Sangat } \\
\text { Segar }\end{array}$ \\
\hline 2 & & Sangat Segar & $\begin{array}{l}\text { Sangat } \\
\text { Segar }\end{array}$ \\
\hline 3 & & Sangat Segar & $\begin{array}{l}\text { Sangat } \\
\text { Segar }\end{array}$ \\
\hline 4 & & Sangat Segar & $\begin{array}{l}\text { Sangat } \\
\text { Segar }\end{array}$ \\
\hline 5 & & Sangat Segar & $\begin{array}{l}\text { Sangat } \\
\text { Segar }\end{array}$ \\
\hline 6 & & Sangat Segar & $\begin{array}{l}\text { Sangat } \\
\text { Segar }\end{array}$ \\
\hline 7 & & Sangat Segar & $\begin{array}{l}\text { Sangat } \\
\text { Segar }\end{array}$ \\
\hline 8 & & Sangat Segar & $\begin{array}{l}\text { Sangat } \\
\text { Segar }\end{array}$ \\
\hline 9 & & Sangat Segar & Segar \\
\hline 10 & & Segar & Segar \\
\hline 11 & & Segar & Segar \\
\hline 12 & & Segar & Segar \\
\hline 13 & & Segar & Segar \\
\hline 14 & & Segar & Segar \\
\hline 15 & & Segar & Segar \\
\hline 16 & & Segar & Segar \\
\hline 17 & & Segar & Segar \\
\hline 18 & & Segar & Segar \\
\hline 19 & & Segar & Segar \\
\hline 20 & & Segar & Segar \\
\hline 21 & & Segar & Segar \\
\hline 22 & & Segar & Segar \\
\hline 23 & & Segar & Segar \\
\hline 24 & & Segar & Segar \\
\hline
\end{tabular}

\begin{tabular}{|c|c|c|}
\hline 25 & Segar & Segar \\
\hline 26 & Segar & Segar \\
\hline 27 & Segar & Segar \\
\hline 28 & Segar & Segar \\
\hline 29 & Segar & Segar \\
\hline 30 & Segar & Segar \\
\hline 31 & Tidak Segar & $\begin{array}{l}\text { Tidak } \\
\text { Segar }\end{array}$ \\
\hline 32 & Tidak Segar & $\begin{array}{l}\text { Tidak } \\
\text { Segar }\end{array}$ \\
\hline 33 & Tidak Segar & $\begin{array}{l}\text { Tidak } \\
\text { Segar }\end{array}$ \\
\hline 34 & Tidak Segar & $\begin{array}{l}\text { Tidak } \\
\text { Segar }\end{array}$ \\
\hline 35 & Tidak Segar & $\begin{array}{l}\text { Tidak } \\
\text { Segar }\end{array}$ \\
\hline 36 & Tidak Segar & $\begin{array}{l}\text { Tidak } \\
\text { Segar }\end{array}$ \\
\hline 37 & Tidak Segar & $\begin{array}{l}\text { Tidak } \\
\text { Segar }\end{array}$ \\
\hline 38 & Tidak Segar & $\begin{array}{l}\text { Tidak } \\
\text { Segar }\end{array}$ \\
\hline 39 & Tidak Segar & $\begin{array}{l}\text { Tidak } \\
\text { Segar }\end{array}$ \\
\hline 40 & Tidak Segar & $\begin{array}{l}\text { Tidak } \\
\text { Segar }\end{array}$ \\
\hline 41 & Tidak Segar & $\begin{array}{l}\text { Tidak } \\
\text { Segar }\end{array}$ \\
\hline 42 & Tidak Segar & $\begin{array}{l}\text { Tidak } \\
\text { Segar }\end{array}$ \\
\hline 43 & Tidak Segar & $\begin{array}{l}\text { Tidak } \\
\text { Segar }\end{array}$ \\
\hline 44 & Tidak Segar & $\begin{array}{l}\text { Tidak } \\
\text { Segar }\end{array}$ \\
\hline 45 & Tidak Segar & $\begin{array}{l}\text { Tidak } \\
\text { Segar }\end{array}$ \\
\hline 46 & Tidak Segar & $\begin{array}{l}\text { Tidak } \\
\text { Segar }\end{array}$ \\
\hline 47 & Tidak Segar & $\begin{array}{l}\text { Tidak } \\
\text { Segar }\end{array}$ \\
\hline 48 & Tidak Segar & $\begin{array}{l}\text { Tidak } \\
\text { Segar }\end{array}$ \\
\hline 49 & Tidak Segar & $\begin{array}{l}\text { Tidak } \\
\text { Segar }\end{array}$ \\
\hline 50 & Tidak Segar & $\begin{array}{l}\text { Tidak } \\
\text { Segar }\end{array}$ \\
\hline
\end{tabular}




\begin{tabular}{|c|c|c|}
\hline 51 & Tidak Segar & $\begin{array}{c}\text { Sangat } \\
\text { Tidak } \\
\text { Segar }\end{array}$ \\
\hline 52 & $\begin{array}{c}\text { Sangat Tidak } \\
\text { Segar }\end{array}$ & $\begin{array}{c}\text { Sangat } \\
\text { Tidak } \\
\text { Segar }\end{array}$ \\
\hline 53 & $\begin{array}{c}\text { Sangat Tidak } \\
\text { Segar }\end{array}$ & $\begin{array}{c}\text { Sangat } \\
\text { Tidak } \\
\text { Segar }\end{array}$ \\
\hline 54 & $\begin{array}{c}\text { Sangat Tidak } \\
\text { Segar }\end{array}$ & $\begin{array}{c}\text { Sangat } \\
\text { Tidak } \\
\text { Segar }\end{array}$ \\
\hline 55 & $\begin{array}{c}\text { Sangat Tidak } \\
\text { Segar }\end{array}$ & $\begin{array}{c}\text { Sangat } \\
\text { Tidak } \\
\text { Segar }\end{array}$ \\
\hline 56 & $\begin{array}{c}\text { Sangat Tidak } \\
\text { Segar }\end{array}$ & $\begin{array}{c}\text { Sangat } \\
\text { Tidak } \\
\text { Segar }\end{array}$ \\
\hline 57 & $\begin{array}{c}\text { Sangat Tidak } \\
\text { Segar }\end{array}$ & $\begin{array}{c}\text { Sangat } \\
\text { Tidak } \\
\text { Segar }\end{array}$ \\
\hline 58 & $\begin{array}{c}\text { Sangat Tidak } \\
\text { Segar }\end{array}$ & $\begin{array}{l}\text { Sangat } \\
\text { Tidak } \\
\text { Segar }\end{array}$ \\
\hline 59 & $\begin{array}{c}\text { Sangat Tidak } \\
\text { Segar }\end{array}$ & $\begin{array}{c}\text { Sangat } \\
\text { Tidak } \\
\text { Segar }\end{array}$ \\
\hline 60 & $\begin{array}{c}\text { Sangat Tidak } \\
\text { Segar }\end{array}$ & $\begin{array}{c}\text { Sangat } \\
\text { Tidak } \\
\text { Segar }\end{array}$ \\
\hline 61 & $\begin{array}{c}\text { Sangat Tidak } \\
\text { Segar }\end{array}$ & $\begin{array}{l}\text { Sangat } \\
\text { Tidak } \\
\text { Segar }\end{array}$ \\
\hline 62 & $\begin{array}{c}\text { Sangat Tidak } \\
\text { Segar }\end{array}$ & $\begin{array}{c}\text { Sangat } \\
\text { Tidak } \\
\text { Segar }\end{array}$ \\
\hline 63 & $\begin{array}{c}\text { Sangat Tidak } \\
\text { Segar }\end{array}$ & $\begin{array}{c}\text { Sangat } \\
\text { Tidak } \\
\text { Segar }\end{array}$ \\
\hline 63 & $\begin{array}{c}\text { Sangat Tidak } \\
\text { Segar }\end{array}$ & $\begin{array}{c}\text { Sangat } \\
\text { Tidak } \\
\text { Segar }\end{array}$ \\
\hline 64 & $\begin{array}{c}\text { Sangat Tidak } \\
\text { Segar }\end{array}$ & $\begin{array}{l}\text { Sangat } \\
\text { Tidak } \\
\text { Segar }\end{array}$ \\
\hline 65 & $\begin{array}{c}\text { Sangat Tidak } \\
\text { Segar }\end{array}$ & $\begin{array}{l}\text { Sangat } \\
\text { Tidak } \\
\text { Segar }\end{array}$ \\
\hline 66 & $\begin{array}{c}\text { Sangat Tidak } \\
\text { Segar }\end{array}$ & $\begin{array}{l}\text { Sangat } \\
\text { Tidak } \\
\text { Segar }\end{array}$ \\
\hline
\end{tabular}

\begin{tabular}{lcc}
\hline 67 & $\begin{array}{c}\text { Sangat Tidak } \\
\text { Segar }\end{array}$ & $\begin{array}{c}\text { Sangat } \\
\text { Tidak } \\
\text { Segar }\end{array}$ \\
\hline 68 & Sangat Tidak & $\begin{array}{c}\text { Sangat } \\
\text { Sidak } \\
\text { Segar } \\
\text { Segar }\end{array}$ \\
\hline 69 & Sangat Tidak & $\begin{array}{c}\text { Sangat } \\
\text { Tidak } \\
\end{array}$ \\
& Segar & Segar \\
\hline 70 & Sangat Tidak & Sangat \\
& Segar & Tidak \\
& & Segar \\
\hline 71 & Sangat Tidak & Sangat \\
& Segar & Tidak \\
& & Segar \\
\hline 72 & Sangat Tidak & Sangat \\
& Segar & Tidak \\
& & Segar \\
\hline 73 & Sangat Tidak & Sangat \\
& Segar & Tidak \\
& & Segar \\
\hline
\end{tabular}

Perhitungan akurasi dilakukan dengan metode Confusion Matrix Multi-Class Classification 4x4 seperti pada Tabel 2.Setelah dilakukan perhitungan didapatkan akurasi dari klasifikasi dengan sistem Neural Network sebesar 95,89\%. Untuk presisi kelas "Sangat Segar (SS)" sebesar 0,8; presisi kelas "Segar (S)" sebesar 1; presisi kelas "Tidak Segar (TS)" sebesar 1 dan presisi kelas"Sangat Tidak Segar (STS)" sebesar 0,9. Setelah presisi semua kelas dijumlahkan dan dibagi banyak kelas didapatkan presisi dari klasifikasi kesegaran udang dengan sistem Neural Network sebesar 92\%.

Tabel 2. Hasil Prediksi klasifikasi Organoleptik kesegaran udang dengan Neural Network

\begin{tabular}{cccccc}
\hline & \multicolumn{4}{c}{ Klasifikasi Organoleptik } \\
\cline { 2 - 5 } & & SS & S & TS & STS \\
\hline Prediksi & SS & 8 & & & \\
\cline { 2 - 5 } neural & S & 1 & 21 & & \\
\cline { 2 - 5 } network & TS & & & 19 & 2 \\
\cline { 2 - 5 } & STS & & & & 22 \\
\hline
\end{tabular}

\section{KESIMPULAN DAN SARAN}

Berdasarkan Hasil pengujian sensitivitas indikator label dari ubi ungu menunjukan bahwa terjadi perubahan warna yang dipengaruhi oleh keberadaan amoniak yang diemisikan oleh udang selama pengujian. sehingga indikator label dari ubi ungu sensitive terhadap keberadaan amoniak.Perbedaan perubahan warna disebabkan jumlah amoniak, semakin lama udang disimpan pada 
suhu ruang, maka jumlah kadar amoniak yang dilepas semakin banyak.Berdasarkan perbandingan antara lama waktu penyimpanan dan kualitas organoleptik udang diketahui bahwa kualitas udang dibedakan menjadi empat kelas, yaitu: yaitu (i) "Sangat segar(SS)" ditandai warna merah pekat (ii) "Segar (S)" ditandai warna biru pekat (iii) "tidak segar" dutandai warna abu-abu dan (iv) "sangat tdak segar" ditandai warna coklat pudar.Melalui klasifikasi citra indikator label menggunakan algoritma neural network dari 73 data training diperoleh tingkat akurasi sebesar 95,89\% dan presisi sebesar $92 \%$

\section{UCAPAN TERIMAKASIH}

Penulis mengucapkan terima kasih kepada Kementrian Pendidikan dan Kebudayaan (Kemdikbud) atas bantuan pendanaan penelitian ini melalui Program Kreativitas Mahasiswa Bidang Riset (PKM-R 2021).

\section{DAFTAR PUSTAKA}

Achmad, Z. \& Sugiarto, B., 2020. Ekstraksi Antosianin dari Biji Alpukat Sebagai Pewarna Alami. Jurnal Teknologi Technoscientia, 12(2), pp. 134-143.

Alimelli, A. et al., 2007. Fish freshness detection by a computer screen photoassisted based gas sensor array. Analytica Chimica Acta, 582(2), pp. 320-328.

Ananta, R., Kusuma, S. B. W. \& Harjono, 2017. Film Berbasis Ekstrak Antosianin Ubi Jalar Ungu Sebagai Bioindikator Kerusakan Daging Ayam. Indonesian Journal of Chemical Science, 6(1), pp. 84-90

Arifuddin, W., 2018. Aktivitas Antioksidan Senyawa Antosianin dari Ekstrak Etanol Ubi Jalar Ungu (Ipomoea batatas L). Jurnal Sains dan Pendidikan Biologi, 1(2), pp. 26-29

Du, L., Chai, C., Guo, M. \& Lu, X., 2015. A Model For Discrimination Freshness Of Shrimp. Sensing and Bio-Sensing Research, Volume 6, pp. 2832.

Fatimah, S. S., Marwanti, S. \& Supardi, S., 2020. Kinerja Ekspor Udang Indonesia di Amerika
Serikat Tahun 2009-2017: Pendekatan Model Constant Market Share (CMS). J. Sosek KP, 15(1), pp. 57-67

Gustina, N., Yuliati, K. \& Lestari, S. D., 2015. Madu sebagai Wet Batter pada Produk Udang Breaded.Jurnal

HasilPerikanan, 4(1), pp. 37-45

Imawan, C., Fitriana, R., Listyarini, A. \& Pudjiastuti, W. S. W., 2018. Kertas Label Kolorimetrik dengan Ekstrak Ubi Ungu Sebagai Indikator Pada Kemasan Pintar untuk Mendeteksi Kesegaran Susu. Jurnal Kimia dan Kemasan, 40(1), pp. 25-32.

Ngginak, J., Semangun, H., Mangimbulude, J. C. \& Rondonuwu, F. S., 2013. Komponen Senyawa Aktif pada Udang Serta Aplikasinya dalam Pangan. Sains Medika, 5(2), pp. 128145 .

Noor, A. et al., 2019. Senduduk (Melastoma malabathricum L.) extract as a green-indicator for monitoring shrimp freshness. Advances in Engineering Research, Volume 167, pp. 167169.

Puspitasari, P. D. 2020. Uji Efektivitas Ekstrak Daun Mangrove Rhizophora Mucronata Sebagai Pengawet Alami Pada Ikan Tongkol (Euthynnus affinis) Dan Udang Vannamei (Litopenaeus vannamei). Skripsi, Program Studi Ilmu Kelautan Fakultas Sains Dan Teknologi Universitas Islam Negeri Sunan Ampel. Surabaya.

Rahmat, A., Patadjai, A. B. \& Suwarjoyowirayatno, 2019. Studi Kualitas Fisika Kimia dan Sensorik Udang Vaname (Litopenaeus vannamei) dengan Perlakuan Soaking Time Sebelum Pembekuan. Journal Fish Protech, 2(1), pp. 46-58

Watson, D., 1939. Studies of Fish Spoilage: IV. The Bacterial Reduction of Trimethylamine Oxide. Journal of the Fisheries Board of Canada, pp. 252-266

Yanto, M., 2017. Penerapan Jaringan Syaraf Tiruan Dengan Algoritma Perceptron Pada Pola Penentuan Nilai Status Kelulusan Sidang Skripsi. Jurnal TEKNOIF, 5(2), pp. 79-87. 